\title{
O Liberalismo Social-Democrata e a Reforma do Estado Brasileiro (1995-2002)
}

\author{
Roberto Antonio Deitos*
}

\section{Resumo}

O artigo consiste numa análise sobre o liberalismo social-democrata e a reforma do Estado brasileiro (1995-2002) como proposiçóes apresentadas nos argumentos de uma facçáo que liderou o processo político e o aparelho de Estado brasileiro a partir de uma coalizáo vitoriosa em 1994 que se compusera a partir das açóes conduzidas pelo PSDB - Partido da Social Democracia Brasileira, facçáo que aglutinou o pacto burguês nacional, expresso na representaçâo da liderança política do intelectual Fernando Henrique Cardoso, eleito presidente da República em 1994. Para tratar dessas questóes, o artigo analisa os aspectos mais gerais da reforma do Estado brasileiro, para compreender como emergiu uma determinada versáo liberal e como seus argumentos políticos e ideológicos consumaram e aglutinaram, a partir de uma determinada facçáo das classes dominantes, a liderança política e econômica do pacto burguês nacional, fortalecido a partir de 1995, com o início dos governos FHC e, consequentemente, com o início de mais uma reforma do Estado brasileiro, culminando com a aprovaçáo, ainda em 1995, do Plano Diretor da Reforma do Aparelho do Estado.

Palavras-chave: Liberalismo. Reforma social. Cardoso, Fernando Henrique. Estado brasileiro.

* Doutor em Educaçáo pela UNICAMP. Professor do Curso de Pedagogia e do Programa de Pós-Graduaçáo em Educaçáo e pesquisador do Grupo de Estudos e Pesquisas em Política Educacional e Social (GEPPES) da Universidade Estadual do Oeste do Paraná (UNIOESTE). 
Neste artigo, analisam-se o liberalismo social-democrata e a reforma do Estado brasileiro ${ }^{1}$, particularmente quanto à atuaçáo de uma facçáo que liderou o processo político e o aparelho de Estado brasileiro a partir de uma coalizáo, vitoriosa em 1994 e composta a partir das açóes conduzidas pelo Partido da Social Democracia Brasileira (PSDB). Tal facçáo aglutinou a representaçáo do pacto burguês nacional, expresso na representaçáo da liderança do intelectual Fernando Henrique Cardoso (FHC), eleito presidente da República em 1994 (BRESSER-PEREIRA, 2003).

Essa facçáo consolidou uma posição política que aglutinou quase a totalidade das classes dominantes ou da maioria de suas fraçóes em um pacto burguês nacional, possibilitando a reforma do Estado como a dinamizadora das açóes políticas, econômicas e financeiras, especialmente no período de 1995 a 2002.

A facçáo política que liderava os dois governos $\mathrm{FHC}$ tinha como pressuposto gerador da crise: a crise do Estado. Crise esta entendida como a ineficiência da gestão estatal, bem como das açóes econômicas que o Estado brasileiro poderia modificar na direçáo da implementaçáo de políticas econômicas, tais como a privatizaçáo e gestáo de empresas ou setores econômicos, tais como energia, telecomunicaçóes, transportes etc, para na visão liberal, tornar-se então mais eficiente e dinâmico em direçáo às necessidades do mercado. Comportadas nessa crise estavam as derivaçóes econômicas, financeiras, políticas e sociais que o país enfrentava para a chamada abertura ao mercado internacional - exigência entendida como derivada da globalizaçáo e da competitividade necessárias para a integraçáo ao mercado mundial -, abarcando a justificativa e os pilares que sustentam material e politicamente o pacto e as reformas implementadas pelo liberalismo social-democrata brasileiro.

Para tratar dessas questóes, este artigo analisa os aspectos mais gerais da reforma do Estado brasileiro, a fim de compreender como emergiu uma determinada versão liberal e como os seus argumentos políticos e ideológicos consumaram e aglutinaram, a partir de uma determinada facçáo das classes dominantes, a liderança política e econômica do pacto burguês nacional, fortalecido a partir de 1995 com o início dos governos FHC e consequentemente com o início de mais uma reforma do Estado brasileiro, e que culminou com a aprovaçáo, ainda em 1995, do Plano Diretor da Reforma do Aparelho do Estado (CARDOSO, 1995). 
No referido plano foram delineadas as dimensóes institucionais e estruturais para o conjunto das reformas que se pretendiam e se empreenderam a partir da reforma do Estado brasileiro na sociedade brasileira ao explicitar os propósitos e as açóes programáticas para as funçóes e açóes estatais. Os pressupostos e os argumentos para tal reforma foram assumidos com a versáo liberal, hegemônica no país, na liderança do pacto burguês nacional, articulado desde a implantação do Plano Real, em 1994, para propor uma nova noção de soberania ${ }^{2}$ para a integraçáo eficiente do país no cenário global e modernizante.

É emblemática a ascensáo do grupo intelectual e político dirigido pelo presidente da República e sociólogo renomado Fernando Henrique Cardoso, particularmente depois do trabalho em que trata de uma determinada visáo do conceito de dependência (CARDOSO; FALETTO, 1973), abarcando um enfoque sociológico em que muitas das afirmaçóes sobre uma economia periférica e sua relaçáo com as economias centrais, e especialmente com a economia mundial, náo sáo contraditórias com as posiçóes políticas adotadas pelo presidente, a ponto de dizer, equivocadamente, que houve uma negaçáo do trabalho do sociólogo na perspectiva intelectual e política do presidente. (FIORI, 1995, 1988, 2001a, 2001b).

As proposiçôes do liberalismo social-democrata vertem os pilares da afirmação de uma postura política renovada e imbricada nas relaçóes e disputas políticas e econômicas que consolidaram as posiçóes e os consensos em que se consumaram os pactos e as disputas que aconteceram, especialmente no Brasil, a partir da implantaçáo do Plano Real, liderado pelo ministro Fernando Henrique Cardoso, ainda em 1993.

Desse modo, portanto, náo se pode dar as costas à capacidade política e intelectual e, consequentemente, econômica que se condensou com as proposiçóes aglutinadas por essa facção política brasileira para uma versáo liberal refinada (FIORI, 2001a, 2001b) das conveniências nacionais, confluindo para a composiçáo das facçóes das classes dominantes para os pactos burgueses firmados, em que as subordinadas foram as classes dominadas.

Essa facçáo liberal está articulada e racionalmente sustentada nas características e nas particularidades engendradas pela composiçáo social brasileira, bem como é convergente com os interesses gerais do capitalismo renovado em seu processo de acumulaçáo em escala mundial, composto, de forma expressiva a partir da década de 1990, por uma mundializaçáo financeira 
ancorada em um processo de acumulação, especulaçáo e parasitismo sem precedentes na história mundial.

Como já revelou Fiori (2001a), é possível compreendermos que, no âmbito nacional, esse processo ganhou uma versáo renovada de um liberalismo que emergiu como fruto da articulaçáo de um grupo de intelectuais brasileiros eruditos e versados - especialmente em um tipo de "marxismo" dogmático e escolástico ou de matrizes weberianas, funcionalistas e positivistas -, os quais ganharam e formularam o brilho e os argumentos político-ideológicos necessários às composiçóes e aos pactos burgueses firmados. Fiori (2001b, p. 285) revela, portanto, que:

Os novos liberais anunciaram o fim das fronteiras e a chegada de um novo renascimento global, e prometeram destruir o nacionalismo anacrônico em nome de um novo conceito de soberania e interesse nacional. Seu diagnóstico era simples: a globalizaçáo era um fato novo, promissor e irrecusável, que impunha uma política de abertura e interdependência irrestrita, como único caminho de defesa dos interesses nacionais, num mundo onde já náo existiriam mais fronteiras nem ideologias. A grande novidade da história recente foi a convergência entre ampla vertente marxista da intelectualidade e os velhos defensores do liberalismo econômico, que sempre estiveram presentes na política como na academia, mesmo durante o auge da hegemonia desenvolvimentista. No caso brasileiro, essa convergência permitiu que se formasse um novo e poderoso bloco político-ideológico, capaz de articular, intelectualmente, uma aliança bem-sucedida entre o que se poderia chamar de "cosmopolitismo de cócoras" de uma parte da intelectualidade paulista e carioca atrelada às altas finanças internacionais, e o localismo dos donos do sertáo e da Malandragem urbana brasileira. Essa aliança de poder está levando até as últimas conseqüências um projeto de transnacionalizaçáo radical de nossos centros de decisáo e das estruturas econômicas brasileiras $[\ldots]$.

Esse liberalismo é mais apropriado e racionalmente renovado, contendo nuances e capacidades que fortalecem e oxigenam as alianças políticas e 
programáticas, salvo alguns conflitos comuns das fraçóes de classe, da velha oligarquia, da velha guarda liberal e, mais significativamente, parte do empresariado industrial e comercial e especialmente dos grupos empresariais, bancários e financeiros nacionais e transnacionais.

Nesse contexto, firmam e dirigem um pacto intelectual, político e econômico capaz de dar roupagem nova e também mediaçóes e condiçóes reais para manter alianças políticas e econômicas programáticas. Esse pacto, dirigido pelos interesses das classes dominantes em âmbito nacional, é sustentado pelo aparelho de Estado como expressáo das relaçôes e das contradiçóes sociais que se expressavam naquele momento. Desse modo, canalizam a consumaçáo eleitoral vitoriosa do pacto burguês nacional e a proclamam como sendo modernizadora ao propor o rompimento com os vícios e as práticas desenvolvimentistas, nacionalistas, burocráticas e populistas que marcaram a história brasileira, particularmente durante os governos de Getúlio Vargas.

A distinção professada expressa uma diferença sobre a função que o Estado ocupa e engendra para os que se autoproclamam sociais-liberais ou sociaisdemocratas, como o presidente da República Fernando Henrique Cardoso, que assumiu como um predicado de seu grupo intelectual e político-partidário esse pressuposto teórico e político. Essa postura revela que mesmo muito antes da realização de "obras social-democratas e modernizadoras" para o Brasil, em sua marcante passagem pelo mais elevado cargo no aparelho de Estado brasileiro, as marcas genuínas dessa versáo do liberalismo já estavam postas na disputa intelectual, eleitoral, econômica e política brasileira (BRESSERPEREIRA, 1996, 1999a, 1999b, 1999c, 2003) e se convertiam e convergiam para uma aglutinaçáo das facçóes das classes dominantes de modo que acabaram possibilitando uma disputa e a condensaçáo de um pacto político e econômico que acabara sustentando a manutenção de um pacto burguês sob a égide da mudança encampada pela mundializaçáo financeira, que se aprofundou depois de 1990, especialmente a partir do anunciado Plano Real ${ }^{3}$, dirigido econômica e politicamente por FHC, como ministro da Fazenda no governo Itamar Franco, e consumado a partir de 1995, no início do seu primeiro governo. Assim, a era FHC consuma o principado da desregulamentação e da flexibilização dos condutores regulatórios e desregulatórios das proposiçóes da mundialização financeira (FIORI, 2001b, p. 285-286).

Esses intelectuais, políticos e empresários brasileiros ligados ao socialliberalismo, ao ascenderem na direção do aparelho de Estado brasileiro - depois 
de plantadas as condiçóes e as mediaçóes políticas e econômicas favoráveis com a consumaçáo do Plano Real, em 1993 - desencadeiam a partir de 1995 um conjunto de medidas governamentais, legais, político-ideológicas e econômico-sociais capazes de engendrar todo um processo de aprofundamento que tem como uma das suas bases e de seus pilares fundamentais a reforma do Estado brasileiro. Consequentemente, mas imbricadas e congruentes a essa reforma, modificaçóes desaguaram nos campos político, financeiro e econômico com profundas e marcantes alteraçóes, que se processam nas condiçóes e particularidades da formaçáo social brasileira, a partir de um conjunto de reformas, preconizadas pelo receituário (neo)liberal, modificado pelas conveniências nacionais, congruentes com as disputas, composiçóes e contradiçóes enfrentadas pela classe dominante.

Desse modo, os liberais compreendem como fundamental a funçáo do Estado como mediador de açóes consideradas essenciais para a existência da liberdade de mercado. O Estado que defendem e cuja reformulaçáo iniciam, consubstancia-se em uma regulamentaçáo que desregulamenta e regulamenta o necessário para as mediaçóes exigidas para o ótimo funcionamento da economia do livre mercado por meio de novas instituiçóes, formadas pelas agências reguladoras em congruência com as açóes tomadas no aparelho de Estado e sob a égide do capital financeiro internacional. Trata-se de um Estado forte que seja capaz de exprimir e gerar as condiçóes da reproduçáo e mediaçáo necessárias ao próprio funcionamento do capitalismo (BRESSER-PEREIRA, 2001, p. 40-41).

As análises do Banco Mundial (BM) e da Corporaçáo Financeira Internacional (CF) estáo convergentes com a necessidade dessas açōes regulatórias, como podemos observar em suas recomendaçóes:

Assim como muitos países em todo o mundo, o governo brasileiro passou por uma grande transiçáo, de ator dominante na economia para se tornar um regulamentador e controlador das funçóes que atualmente sáo privadas [...]. (BANCO MUNDIAL; CORPORAÇĀO FINANCEIRA INTERNACIONAL, 2001, p. 33).

Convergindo a essa direçáo, o presidente FHC, quando avaliava as metas de seu governo, considerava que: 
O crescimento econômico resulta da conjugaçáo de quatro ordens de fatores: 1) elevada taxa de poupança e investimento; 2) apropriada qualificaçáo da máo de obra; 3) desenho institucional que favoreça a eficiente aplicaçáo de recursos produtivos; 4) ambiente macroeconômico estável. (BRASIL, 1998, p. 5).

O Estado assume funçáo primordial e, contrariando os prognósticos apressados, os seus promotores, os liberais, valendo-se da retórica do estatismo intervencionista ou do burocratismo ineficiente, reafirmam o Estado brasileiro como central no processo de acumulaçáo e reorganizaçáo das relaçóes produtivas e financeiras, selando mais um período de estabilidade e governança a partir do pacto burguês sob o controle das classes dominantes, em detrimento, consequentemente, dos interesses das classes dominadas.

Para os liberais, especialmente para os que irăo dirigir o processo da necessidade de governança, incluindo o domínio político do aparelho estatal, o Estado brasileiro assume uma dimensáo singular no processo de coordenaçáo política e econômica. Considerando o Estado como fundamental para o processo de "modernizaçáo" brasileira, em 1995 o governo FHC inicia uma profunda reforma do Estado brasileiro.

Essa reforma esteve sob uma ótica e versáo liberal que historicamente acabou predominando desde a sua constituiçáo, tendo o Estado e o mercado como componentes de um mesmo corpo constituinte do capital e da sociedade dividida em classes sociais, servindo e compondo as mediaçóes com as classes dominadas, para a viabilidade e a estabilidade de ganhos financeiros e políticos dentro da ordem social estabelecida. Assim, o Estado é a expressáo de relaçóes de poder e de classe, produzindo mediaçóes que culminam com a solidificaçáo dos interesses das classes dominantes. Para os liberais, na expressáo de um dos seus maiores representantes:

Reformar o Estado náo significa desmantelá-lo. Pelo contrário, a reforma jamais poderia significar uma desorganizaçáo do sistema administrativo e do sistema político de decisóes e, muito menos, é claro, levar à diminuição da capacidade regulatória do Estado [...]. (CARDOSO, 1999, p. 15). 
Essa mesma perspectiva é também adotada para o programa de reformas educacionais proposto no governo FHC. Ao se referir à necessidade do aumento da percentagem do Produto Interno Bruto (PIB) destinado à educaçáo, Mello (1990, p. 58), com a mesma clareza teórica e perspectiva política, afirmava:

[...] é preciso considerar, em primeiro lugar, que esse aumento da percentagem do PIB destinado à educaçáo está condicionado à recuperaçáo da capacidade de investimento do setor público e, portanto, estreitamente dependente da superação da crise econômica e de uma profunda e eficaz reorientaçáo do papel do Estado na economia.

Foi sempre nessa direçáo que as reformas que emergiram durante os governos FHC foram regradas, isto é, pautavam-se em uma clareza da necessidade e da função do Estado brasileiro na atuaçáo dos mecanismos de mercado, privatizando empresas estatais, alterando regimes de trabalho dos servidores e dos trabalhadores em geral, interferindo econômica e financeiramente e flexibilizando e instituindo agências reguladoras nacionais, as quais tratariam dos serviços considerados exclusivos e náo exclusivos do Estado. Considera-se que:

Os Estados modernos contam com três setores: o setor das atividades exclusivas de Estado, dentro do qual estáo o núcleo estratégico ${ }^{4}$ e das agências executivas ou reguladoras; os serviços sociais e científicos, que náo săo exclusivos, mas que, dadas as externalidades e os direitos humanos envolvidos, demandam, do ponto de vista técnico e ético, forte financiamento do Estado; e, finalmente, o setor de produçáo de bens e serviços para o mercado (BRESSER-PEREIRA, 2001, p. 36).

Para Bresser-Pereira (2001), a reforma do Estado brasileiro iniciada em 1995 pode ser considerada um projeto bem-sucedido, principalmente pelas mudanças constitucionais e culturais que empreendeu, especialmente ao flexibilizar a contrataçáo de pessoal para os serviços públicos, criando o regime de emprego público em oposiçáo ao cargo público.

Assim, foram instituídas mudanças trabalhistas e criaram-se as agências reguladoras, dotadas de autonomia, como agências executivas, além das organizaçóes sociais para prover serviços que o Estado náo necessariamente teria a obrigaçáo de oferecer assegurados através de contratos de gestáo que se firmariam com o núcleo estratégico do Estado (BRESSER-PEREIRA, 2001). 
Para diferenciarem-se e mostrarem a renovação a que estáo dispostos, os nossos liberais estabelecem algumas diferenças com outras facçóes liberais, por entenderem que:

[...] a transição do 'Estado produtor' para o 'Estado gerencial' vai além de criar agências reguladoras: é também o Estado democrático e eficiente que financia a fundo perdido os serviços sociais e a pesquisa científica e age como capacitador (enabler) da competitividade das empresas privadas. (BRESSER-PEREIRA, 1999b, p. 30).

Bresser-Pereira (1999c) entende que a reforma foi bem-sucedida durante o processo que se realizou no período entre os anos de 1995 e 1998, quando foram consolidadas algumas das principais bases político-ideológicas e jurídicoinstitucionais para a efetivação das reformas previstas.

Como um dos mentores intelectuais da reforma do Estado brasileiro, Bresser-Pereira (1999b, p. 33) entendia que a iniciativa "cultural e institucional" produzida com a chamada reforma gerencial do Estado brasileiro tornou-se referência empírica para muitos países, especialmente os latino-americanos e, por isso, foi incorporada na formulaçáo do documento Uma nova gestáo pública para a América Latina, elaborado pelo Conselho Latino-Americano de Administraçáo para o Desenvolvimento (CLAD), e, desse modo, tornandose indicativo de ajustes institucionais defendidos pelo Banco Mundial e pelo Banco Interamericano de Desenvolvimento (BID) para a reforma do Estado nos países latino-americanos.

As mediaçóes que o Estado pode realizar reorganizando poderes, distribuindo funçōes e criando novas instituiçōes jurídicas e econômicofinanceiras sáo compreendidas como características primordiais do Estado concebido pelos nossos liberais. Eles conceituam com distinçáo e definem as especificidades da composiçáo e das mediaçóes que constituem a reforma do Estado brasileiro que desejam efetivar, estando na direçáo do aparelho de Estado ou fora dele, governando a partir do pacto das classes dominantes - particularmente daquelas "rotuladas" ou afinadas com as tendências "modernizantes", sopradas pelos ventos da mundializaçáo financeira. Para o que se propunham, "O problema central da reforma náo é escolher entre estratégias de gestáo, mas criar instituiçóes que viabilizem a adoçáo de tais estratégias" (BRESSER-PEREIRA, 1999b, p. 34). 
As velhas e as novas funçóes estatais e o núcleo estratégico do Estado brasileiro moderno, para Bresser-Pereira (2001, p. 36-37), comportariam, portanto:

As atividades exclusivas, que săo aquelas que envolvem o poder de Estado e que implicam um poder extroverso com relaçáo ao Estado, na medida em que este, enquanto aparato, é a única organizaçáo com poder para regular náo apenas os próprios membros da organizaçáo, mas os de toda a sociedade [...].

Sobre a propriedade náo estatal, o autor apresenta a direçáo distinta para que se move a reforma do Estado brasileiro, considerando que:

Se náo têm, necessariamente, de ser propriedade do Estado nem de ser propriedade privada, a alternativa é adotar-se o regime da propriedade pública náo estatal, isto é, utilizar organizaçóes de direito privado, mas com finalidades públicas, sem fins lucrativos. (BRESSERPEREIRA, 2001, p. 38-41)

A defesa da gratuidade é do mesmo tamanho da liberdade preconizada pelos pressupostos de nossos liberais, em que o mercado estabelece as oportunidades e dinamiza a circulaçáo e a seleçáo dos mais eficazes e eficientes, sejam instituiçóes estatais, privadas ou náo estatais, como as que se propunha na reforma. O que os liberais náo conseguem negar, com ou sem contrato de gestáo, é que, no ponto de chegada, sempre esperando de braços abertos, está o mercado.

Os nossos liberais, quando renovam sua defesa do mercado, de forma civilizada e com a escora estatal aceitável, explicitam, contrariando os "lapsos estatizantes", como se dariam, no ponto de chegada as açóes de gestáo dos serviços sociais:

[...] no setor dos serviços náo-exclusivos de Estado, a propriedade deve ser em princípio pública náo-estatal. Deve ser pública para justificar os subsídios recebidos do Estado. O fato de ser pública náo-estatal, por sua vez, implica a necessidade de a atividade ser controlada de forma mista pelo mercado e pelo Estado. (BRESSERPEREIRA, 1999c, p. 263). 
O serviço mais árduo a que se prestam os nossos sociais-liberais a serviço do país estaria em "[...] oferecer uma alternativa ao individualismo radical da nova direita neoliberal” (BRESSER-PEREIRA, 2001, p. 44), certamente compondo um pacto burguês, em que essa direita neoliberal coaduna com um bloco de poder, a que essa facção teórica corresponde, e aceita as intençóes políticas e as práticas realizáveis que se punham a desempenhar, com grande competência e qualidade, os novos liberais modernizantes. Os nossos novos liberais tornam-se os porta-vozes e os destacados dirigentes na tarefa de reorganizar e ampliar as esferas estatais em direçáo ao mercado e a partir da crença "profética" nele.

Essa é a reforma do Estado eficiente do social-liberalismo, que náo quer ser chamado de direita e náo gosta de ser confundido com a direita neoliberal, mas aglutina as duas e faz a terceira via para os novos liberais avançados e modernizantes com o nome apreciável e refinado que desejam adotar, porque, na verdade, conseguem propor a forma mais consistente de mediaçáo privada pelos mecanismos estatais concentrando um pacto das classes dominantes extremamente vantajoso e relativamente estável em razáo de seus desdobramentos econômico-financeiros arrojados - tais como a privatizaçáo de empresas e espaços que eram estatais - e dos mecanismos processuais de financeirizaçáo alargados pelas açóes regulatórias estatais, pelos mecanismos de intermediaçáo e subsídios protecionistas às classes dominantes e pelo processo de encilhamento financeiro envolvendo os fenômenos da dívida interna $\mathrm{e}$ externa e da reproduçáo da acumulaçáo gerado pela venda de títulos públicos com rentabilidade garantida às classes proprietárias e parasitárias.

Só náo é um Estado perfeito para determinadas facçóes de liberais porque algumas, mais que outras, querem os proveitosos benefícios promovidos pelo Estado, que tanto combatem, com os quais muito se saciam.

Os pressupostos definidores da reforma do Estado brasileiro, a partir do que se definiu com a reforma desencadeada principalmente com o governo FHC, alardeiam as condiçóes favoráveis do mercado, sem, no entanto, dispensar o Estado. Afirmam a proposiçáo da administraçâo gerencial como uma diferenciadora da relaçáo e açấo estatal. Náo há, portanto, a negação do mercado e do Estado, pois o mercado é guia do Estado e por isso é protegido por ele. Sendo assim, a reforma gerencial implementada "é social-liberal, enfim porque acredita no mercado como um ótimo, embora imperfeito, alocador de recursos, além de procurar restringir a açáo do Estado às áreas em que o mercado está ausente, realiza mal sua tarefa coordenadora." (BRESSER-PEREIRA, 2001, p. 42-43). 
O Estado que defendem e de que usufruem jamais significou a negaçáo do mercado, que náo foi colocado em um plano secundário na relaçáo com o Estado, como aparentemente parecem querer enfocar algumas interpretaçóes dos liberais ou das facçóes liberais. Muito pelo contrário, a direção é definitiva e compreende que:

[...] sáo essenciais uma reforma política que dê maior legitimidade aos governos, o ajuste fiscal, a privatizaçáo, a desregulamentaçáo - que reduz o 'tamanho' do Estado - e uma reforma administrativa que crie os meios de se obter uma boa governança. (BRESSER-PEREIRA, 1999b, p. 36).

O Estado é efetivamente concebido em sua constituição como a materialidade capaz de, em condiçóes sociais e politicamente defensáveis, expressar as mediaçóes e impor um pacto das classes dominantes sobre as classes dominadas, sustentando e dando forma à chamada governança neoliberal: "A diferença entre uma proposta de reforma neoliberal e uma social-democrática está no fato de que o objetivo da primeira é retirar o Estado da economia, enquanto o da segunda é aumentar a governança do Estado." (BRESSERPEREIRA, 1999c, p. 237-238).

Segundo a perspectiva social-liberal, as grandes incumbências de sanar as necessidades sociais nacionais (como saúde, educaçáo e pesquisa científica), se náo são tidas como exclusivas do Estado, também náo apresentam, por causa das dificuldades laterais e externalidades, condiçóes de ficar somente sob o comando do mercado, apesar de serem entendidas como incumbências de sua alçada.

A proposição defendida, então, seria a formação de organizaçóes sociais coordenadas pelo setor público náo estatal, sem que isso possa significar o enfraquecimento do poderio do Estado capitalista. Muito pelo contrário, a formaçáo dessas organizaçóes deve implicar ampliaçáo da sua capacidade de gestáo convergente e alimentadora do processo de reproduçáo e acumulaçáo do capital.

Há uma preocupação em estabelecer diferenciaçóes para as traduçóes, que são concebidas das conveniências econômicas e políticas que se consolidadas, considerando-se as características peculiares da formaçáo social em que se desenvolvem e as fraçóes de classes dominantes em disputa pela hegemonia do processo de acumulação e de poder no Estado brasileiro. 
Disso decorre que o diagnóstico para caracterizar a reforma do Estado gera críticas ao patrimonialismo, ao burocratismo, ao populismo e ao autoritarismo para que sejam intituladas como modernizantes em relaçáo a essas posiçóes políticas e econômicas consideradas radicais, sejam elas do campo da direita ou da esquerda revolucionária. Assim, projeta-se a reforma como sendo uma resposta à crise que se configurou a partir da década de 1980. Dentre as justificativas centrais, estaria a necessidade de os mercados nacionais se abrirem incondicionalmente à competitividade internacional, integrando-se a ele de modo eficiente e competente.

Ainda, com relaçáo ao diagnóstico da crise que provocou um suposto Estado ineficiente e burocrático, na opiniáo dos proponentes da reforma:

A crise política teve três momentos: primeiro, a crise do regime militar - uma crise de legitimidade; segundo, a tentativa populista de voltar aos anos 50 - uma crise de adaptaçáo ao regime democrático; e finalmente, a crise que levou ao impeachment de Fernando Collor de Mellouma crise moral. (BRESSER-PEREIRA, 1999c, p. 239).

As reformas, porém, somente ganham força e consistência quando contam com o "[...] fundamental apoio das facçóes modernizantes do país, que necessariamente inclui a alta administraçáo pública." (BRESSER-PEREIRA, 1999c, p. 267). Isso inclui um amplo bloco reformista alicerçado por essas ilustres facçöes modernizantes. Tanto que:

[...] Os problemas de governabilidade não decorrem do 'excesso de democracia', do peso excessivo das demandas sociais, mas da falta de um pacto político ou de uma coalizáo de classes que ocupe o centro do espectro político [...]. Nosso pressuposto é de que o problema político da governabilidade foi provisoriamente equacionado com o retorno da democracia e a formaçáo do 'pacto democrático-reformista de 1994', possibilitada pelo êxito do Plano Real e pela eleiçáo de Fernando Henrique Cardoso. (BRESSER-PEREIRA, 1999, p. 238).

Ao tratar o processo administrativo e político e de como viabilizar a materializaçáo da transferência estatal para o mercado, a transiçáo proposta 
estabeleceu os parâmetros do jogo e as condiçóes para o ponto de partida da reforma do Estado brasileiro.

Para transformar os serviços náo-exclusivos de Estado em propriedade pública náo-estatal e declará-los uma organização social será necessário um 'programa de publicizaçáo', que náo deve ser confundido com programa de privatizaçáo, na medida em que as novas entidades conservaráo seu caráter público, mas de direito privado, assegurando, assim, uma autonomia administrativa e financeira maior. Para tanto será preciso extinguir as atuais entidades e substituí-las por fundaçóes públicas de direito privado criadas por pessoas físicas [...] (BRESSER-PEREIRA, 1999c, p. 263-264).

Bresser-Pereira (1999c) considera que foram realizadas algumas reformas administrativas no Brasil. A primeira reforma administrativa teria ocorrido na década de 1930 (entre 1937 e 1938, durante a ditadura do Estado Novo Varguista). Nessa reforma foi criado, em 1938, o Departamento Administrativo do Serviço Público (DASP). A segunda reforma aconteceu em 1967, durante a ditadura militar iniciada em 1964, e foi coordenada pelo ministro do planejamento Hélio Beltrão. Por fim, entre 1979 e 1983, na gestáo do agora ministro da desburocratizaçáo Hélio Beltráo, foi realizada uma iniciativa considerada por ele como sendo proveitosa.

Percebe-se que os períodos mencionados como de possíveis avanços na reforma administrativa e do Estado brasileiro sob o ponto de vista da suposta administraçáo moderna gerencial, descrita e defendida pelo ministro BresserPereira (1999b), ilustram como reformas administrativas elogiáveis e proveitosas as que ocorreram em períodos autoritários: a primeira foi concebida e produzida na ditadura do Estado Novo e segunda, na ditadura de 1964.

A gestão de Hélio Beltrão é destacada, na perspectiva "gerencial", como uma iniciativa louvável que se configura durante a ditadura militar. Já as reformas empreendidas na chamada transiçáo democrática, com a eleiçáo indireta de Tancredo Neves e a posse de José Sarney, em março de 1985, náo se apresentam como uma perspectiva de reforma do aparelho de Estado, segundo os pressupostos da administraçáo gerencial apresentados no Plano Diretor da Reforma do Estado. Desse modo, náo se enquadram com qualquer 
substância, mesmo que de relativa significância, aos desígnios pretendidos pelos reformuladores e modernizadores do Estado brasileiro.

Em relaçáo às mudanças instituídas pela Constituiçáo de 1988, o entáo ministro da Reforma do Estado, Bresser-Pereira (1999c), considerava que na Carta Constitucional havia ocorrido um retrocesso burocrático com relaçáo aos pressupostos da administraçáo "gerencial", os quais sugerem demandas com o propósito de imprimir alteraçóes constitucionais para o seu ajustamento às necessidades previstas pela "modernizaçáo" preconizada com a reforma do Estado brasileiro, vislumbrada com a apresentaçáo e aprovaçáo do Plano Diretor da Reforma do Estado.

Dessa forma, o autoritarismo (não que esse seja o único elemento) parece náo incomodar as pretensōes, as perspectivas e a modernizaçáo que se propunha com a reforma administrativa e do Estado na perspectiva "gerencial" implementada pelo governo FHC sob a direçáo de um mentor habilidoso e teoricamente posicionado e empenhado.

As únicas propostas e alternativas de reforma administrativa e do aparelho do Estado realizadas na história brasileira que possuem alguma consideração na direção da perspectiva "gerencial" foram realizadas em períodos de autoritarismo: durante o governo de Getúlio Vargas e no Golpe de 1964. Entretanto, parecenos que o elemento central náo estaria no autoritarismo, mas na lógica e dinâmica que alimenta e move a reforma administrativa em uma perspectiva "gerencial", sob a égide do mercado e das premissas doutrinárias de uma versão liberal clássica, em que o mercado e a propriedade privada sáo condiçóes prévias para a liberdade individual.

Sendo assim, a política é condicionada pela liberdade individual, que só existe como a condiçáo material que se processa no mercado a partir da propriedade privada. Dessa forma, o regime político torna-se uma condiçáo secundária, pois estaria subordinado às vontades individuais, sustentadas e legitimadas na privacidade que, em última instância, só o mercado e a propriedade poderiam realizar, seja econômica, social ou politicamente. (FRIEDMAN, 1984).

Nossos liberais social-democratas náo comungam, em suas perspectivas teóricas, da aceitação do autoritarismo na versảo conhecida, por exemplo, a versáo do regime militar de 1964 ou mesmo a da ditadura de 1937. Defendem que o pacto burguês possa ocorrer e fluir sustentado também no âmbito de uma 
política de coalizáo ancorada no sufrágio eleitoral. Isso acentua, para nossos novos liberais modernizantes, a capacidade de gerenciamento e a eficiência da estabilidade política e da governança no aparelho de Estado.

$\mathrm{Na}$ direçáo dessa perspectiva, os mecanismos "democráticos", de "governabilidade" e de "controle estatal" estáo sujeitos ao consenso pactuado pelas fraçóes das classes dominantes modernizantes, uma coalizáo que deve promover a sociedade cidadá e republicana. Ou seja, essas fraçóes modernizantes estariam em uma posiçáo claramente definida. Primeiro, por náo concordarem com o estatismo deliberado; segundo, por concordarem que o mercado possa sofrer intervençóes regulatórias; terceiro, por que compreendem a dimensáo que o Estado assume na constituiçáo do próprio capitalismo, seja nas sociedades centrais ou nas sociedades periféricas; quarto, por que estão determinadas, econômica e politicamente, a avançarem na "modernizaçáo" do Estado, contemplando as agências reguladoras como mecanismos de contraposiçáo ao estatismo e, ao mesmo tempo, da negaçáo do Estado como interventor na economia, mas sem deixar de tê-lo como seu importante promotor; e, quinto, por reconhecerem o mercado como um promissor regulador de açóes sociais, inclusive estatais e, por isso, quererem e defenderem um tipo determinado de governança estatal, reconhecendo que a economia de mercado está na própria estrutura institucional, que dela se nutre como um componente, com o capital, da sua própria constituiçáo.

O capitalismo náo prescindiu das açóes estatais, mas é nelas que ganha corporeidade e estabilidade de reproduçáo e acumulaçáo de capital. O Estado, desse modo, é constituinte do capitalismo assim como o capitalismo é constituinte do Estado, que é resultante das relaçōes e mediaçōes que se materializam com a luta de classes e compóem o processo de produçáo, circulaçáo e acumulaçáo de capital. Desse modo, não se separa capital, trabalho e Estado, compondo relaçóes que se reproduzem e se consomem em um sociometabolismo reprodutivo, constante e contraditório (MÉSZÁROS, 2002).

Assim, o Estado só pode ser compreendido em sua constituiçáo com o capital e o trabalho. Essa relaçáo constituinte do Estado mostra as suas fissuras e contradiçóes, bem como as características dominantes em cada período de formação social determinada historicamente e articulada mundialmente.

Jamais o Estado, que assume formas determinantes e particulares no modo de produçáo capitalista e na sua composiçáo em determinada formaçáo social, constitui-se fora do âmbito das relaçóes de poder e da luta de classes. Porém, 
essas características são dissimuladas pela consolidação e pelas mediaçóes que emergem do pacto burguês na sociedade do livre mercado (SODRÉ, 1996, p. 25-26).

Seráo, portanto, as suas contradiçóes de classe e as relaçóes de produçáo, trabalho e acumulação de capital que daráo a condensaçáo fundamental ao processo de reproduçáo engendrados nas relaçóes de poder e de classe que o Estado permite articular e estabelecer em uma sociedade capitalista e, consequentemente, em que as classes dominantes exploram as classes dominadas utilizando vários mecanismos e componentes sociais, políticos, produtivos, psicoideológicos e linguísticos disponíveis para explicar as estruturas sociais e sustentar ideologicamente a ordem social estabelecida.

Há o refinamento da justificativa e da compreensáo de que o mercado e o Estado estáo embrenhados na mesma dinâmica constitutiva do capitalismo e que a mediaçáo realizada pelo Estado é central para o processo de acumulaçáo de capital e de manutençáo de determinada política, de determinado poder político e dos próprios mercados. Esse processo acaba fornecendo fluidez e eficiência para o seu funcionamento e constitui o alicerce em que são instituídas novas competências e estratégias para justificar as suas necessidades e dar conta das relaçóes, mediaçóes e dos pactos que se estabelecem sob a égide das classes dominantes e que consagram materialmente vitórias sobre as necessidades e demandas de classe, estabelecidas pelas classes dominantes linguística e publicitariamente, justificadas como resultantes de concessóes políticas e sociais às classes dominadas na hierarquia social desigual e competitiva, e acobertadas com a manutençáo do pacto burguês nacional.

Coerente com essa dinâmica, nossos liberais modernizantes compreendem que

À medida que se tornava claro que a proposta neoconservadora ou neoliberal de atribuir ao mercado toda a coordenaçáo da economia e reduzir o Estado ao mínimo náo era realista, náo correspondendo nem aos anseios da sociedade nem às necessidades das economias nacionais, a questáo da reconstruçáo do Estado e da reforma de seu serviço civil tornou-se central. (BRESSER-PEREIRA, 1999a, p. 7). 
Congruente com essas novas exigências, o mais ilustre dos representantes de nossos liberais demonstra total clareza de direçáo e de alvo que se quer atingir quando, em uma de suas entrevistas, ao ser solicitado a responder quem estaria fazendo crítica inteligente ao seu governo, respondeu:

Roberto Campos também faz, mas pelo outro lado. Não concordo. Ele é liberal. Quer realmente que o Estado diminua. Que regulamente menos. Outro dia ele fez uma crítica a mim. Disse que não sou um "convertido". Tem razáo. Não sou mesmo convertido a essa visáo de um Estado que náo regulamenta. O que estamos fazendo na prática? Criando agências de regulamentaçăo. Privatizando e criando agências de regulamentaçáo [...] (CARDOSO, 1997, s/p).

A distinçáo exposta demonstra a dimensáo desse liberalismo que o presidente Fernando Henrique Cardoso proclama e realiza. Há uma nítida percepçáo da necessidade de açóes regulatórias estatais em relaçáo à boa governança, que só ocorre quando o mercado conta com a sua fluidez oxigenada pelo Estado. Tal perspectiva tem o aval de outro ilustre intelectual e aliado político quando este relatava, uma década antes do início formal do governo FHC, como devia pensar um economista progressista sobre a intervençáo do Estado na economia, enumerando as principais açóes que o Estado deveria executar, particularmente no campo econômico.

A questáo básica em discussáo é a capacidade do mercado de regular automaticamente a economia ou da sua incapacidade de realizar essa tarefa. Neste último caso, o economista progressista defende a necessidade de um certo grau de intervençáo do Estado [...] (BRESSERPEREIRA, 1985, p. 7).

Assim, náo há como confundir os pressupostos. Estes assumem nitidez ainda maior quando sáo os nossos liberais modernizantes que os proclamam e definem. Como liberal modernizante e renovador, Bresser Pereira (1985) aponta suas próprias distinçóes e esclarece suas posiçóes com brilhantismo, convicçáo e fundamentaçáo teórica. Ao caracterizar um economista progressista, compara-o ao economista conservador. Em síntese, revela que o economista "conservador é aquele que pretende antes conservar do que reformar a ordem estabelecida" 
(BRESSER-PEREIRA, 1985, p. 6), já o economista "progressista é quem está mais preocupado com a justiça do que com a ordem" (BRESSER-PEREIRA, 1985, p. 6).

Desse modo, náo deixa dúvidas de que um economista progressista é um economista liberal, chamando a atençáo para o fato de que o termo liberal deve compreendido no âmbito da linguagem anglo-saxá. (BRESSER-PEREIRA, 1985 , p. 6). Náo permite, portanto, que ocorra dúvida sobre o campo do socialliberalismo, em que estáo imbuídos muitos de nossos liberais e que apenas renova e fortalece os trilhos percorridos pelo nosso liberalismo. Tanto que, ao criticar as posiçóes e distorçóes entre liberais conservadores e progressistas, tomados aqui na própria dimensáo expressa por Bresser-Pereira, adverte que " [...] o mercado continua a ser a instituiçáo reguladora fundamental do sistema capitalista, náo podendo ser ignorado nem substituído" (BRESSER-PEREIRA, 1985, p. 13).

Corroborando a perspectiva defendida, seu náo menos ilustre aliado político, Fernando Henrique Cardoso, ao apresentar o Plano Real em dezembro de 1993 e mencionar a necessidade premente de revisáo constitucional (CARDOSO, 2003. p. A4), anunciava alguns dos problemas do Estado. Para esses problemas, propunha soluçóes por meio do Estado, pois a crise diagnosticada tinha nele mesmo o seu ponto de culminância e não teria sido suficientemente abarcada e enfrentada à base de competência e eficiência com a Constituinte de 1988 (CARDOSO, 1994, p. 122).

A reforma do Estado, inserida prioritariamente na revisáo constitucional proposta pelos nossos liberais, carrega grande significado e materialidade política e econômica. Por isso, náo hesitam em dizer que:

Mais do que um passo necessário para a estabilizaçáo da economia, e até para que a estabilidade seja duradoura, a Revisão é fundamental por suas implicaçóes de longo prazo. Ela é a oportunidade de definir com nitidez o perfil do Estado desejado pela sociedade brasileira e de desatar as amarras constitucionais [...]. (CARDOSO, 1994, p. 122).

Ao se referir, na Exposição de Motivos do Plano Real, à componente modernizaçáo da economia, $\mathrm{FHC}$ vincula-a com a proposta da componente revisáa constitucional, sendo esta uma determinante central à realizaçáo daquela. Por isso, afirmava, sobre a proposição de modernizaçáo da economia que defendia: 
[...] a eliminaçáo das restriçóes ao capital estrangeiro na exploraçáo do subsolo e das fontes de energia hidráulica. Também aqui o fundamental, para que se resguarde o interesse nacional e popular, é reforçar o poder regulador do Estado neste tipo de exploraçáo, feito por empresas estatais ou privadas, nacionais ou estrangeiras. É esta a noçáo moderna de soberania que está faltando: Governo e sociedade atentos organizadamente ao desempenho das empresas que exploram áreas essenciais para o desenvolvimento do País e para o bem-estar coletivo. (CARDOSO, 1994, p. 126).

De acordo com a sua Exposiçáo de Motivos, o Plano Real pressupunha em uma de suas justificativas, entre inúmeras mudanças e alteraçóes econômicas, financeiras, administrativas e sociais propostas, que a realizaçáo de tais mudanças promoveria a noçáo moderna de soberania que estava faltando ao país. Demonstrava, ainda, que a nova moeda criada possibilitaria, no que se refere à dívida brasileira, uma generosa melhoria da securitização (titulos da dívida pública) com a salvaguarda dos títulos da dívida federal em novas condiçóes, vislumbradas com a nova e redentora moeda chamada Real.

$\mathrm{Na}$ área social, como desdobramento dos ajustes modernizantes, as mudanças seriam geradas a partir da reforma do Estado e da consequente modernizaçáo econômica, que, de acordo com a Exposiçáo de Motivos do Plano Real, propunha-se a romper mazelas e distribuir melhor a renda e a riqueza. Assim, a nova moeda, o Real, é a pré-condição, a condição e a encarnação nacional do rompimento da miséria social.

Os liberais consideram que o Plano Real é fundamental à naçáo e à melhoria de alguns de seus maiores problemas, como o crescimento, o emprego, a distribuiçáo de renda e da riqueza, bem como para a realizaçáo de autonomia em relação ao aparelho de Estado de instituiçóes e a criação de agências reguladoras como um passo determinante ao paraíso orientado pela crença no mercado. Neste caso em particular, encontra-se o Banco Central do Brasil que, náo estando adequado ainda à noção moderna de soberania, não gera maior competitividade que o Estado deve possibilitar para uma maior flexibilidade regulatória e para a promoçáo do mercado.

Os liberais, como Milton Friedman (1984), dos EUA, não abrem máo do termo liberalismo no embate entre liberais e neoliberais, mas a disputa central 
entre eles encontra-se na questão da intervenção ou não do Estado na economia. A soluçáo para os problemas advindos da dinâmica do capitalismo, no fundo, como professa Friedman, encontra-se nas premissas do próprio liberalismo, das quais não abre mão. As disputas das facçóes dissimulam as contradiçóes fundamentais em que se sustentam essas premissas e os receituários por elas prescritos.

No Brasil, os liberais modernizantes e renovadores, para se distinguirem das facçóes liberais de que divergem teoricamente, se autoproclamam sociaisliberais, ou progressistas. Mas afirmam que, ao final da conversa, sáo todos liberais e, na prática, adoram o Estado brasileiro. $\mathrm{Na}$ verdade, esses sociaisliberais são mais competentes ao enfrentarem o tensionamento entre Estado e mercado. Promovem sempre o mercado, nunca prescindindo do Estado, compreendido como fundamental para a própria existência do processo de acumulaçáo do capital. Eis onde encontra-se a fraçáo avançada dos liberais modernizantes.

As proposiçóes oriundas das justificativas anunciadas pela Exposiçáo de Motivos do Plano Real sáo táo reais como premissas do liberalismo econômico quanto à retórica que exprime melhor distribuiçáo de renda e riqueza. Isso é real e nossos liberais, distintos em suas nuances políticas, são semelhantes e convergentes, em seus propósitos de classe, quanto à conveniência do liberalismo que proclamam e o liberalismo que realizam (BRESSER-PEREIRA, 1985, p. 14). Nada mais ideologicamente condicionado que a açáo dos economistas conservadores ou progressistas, que são certos de que "A economia é uma ciência social e, portanto, uma ciência ideologicamente condicionada [...]". (BRESSER-PEREIRA, 1985, p. 5). Bresser-Pereira (1985) tem razáo quando esclarece esse pressuposto sobre a sua compreensáo da economia ao dar ênfase às características ideológicas da economia.

No campo da reforma do Estado, afirmam suas posiçóes e dáo maior materialidade às mediaçóes de classe e maior visibilidade ao pacto e às açóes estatais. Náo estáo equivocados, portanto, ao nutrir seus argumentos de que fundamentalmente o centro da crise está na crise do Estado. As determinaçóes econômicas, sociais e as da luta de classes sáo tidas como secundárias e derivadas da crise do Estado, em última instância. Por isso, globalização, competitividade e integraçáo são componentes vislumbrados pela reforma do Estado e só seráo enfrentados a partir dela, que é fundada na noçáo moderna de soberania como uma projeçáo e "profecia" para o futuro. 
Essa preocupaçáo de nossos liberais modernizantes e renovadores, que vislumbravam o futuro, já condicionava que os problemas do país eram determinantemente de ordem interna e os colocavam, diante das implicaçóes e determinaçóes externas, como um problema de gestâo e de integração ao mercado mundial, sendo este diagnosticado como movido por uma economia mundial cada vez mais competitiva e tecnologicamente avançada. Certamente, as relaçóes internas determinam nossa posiçáo nas relaçóes externas ao estarem produzindo-se e reproduzindo-se nas relaçóes internas.

As facçóes liberais encarnadas como modernizantes e renovadoras convergem na avaliaçáo de que a tarefa de casa náo está sendo bem feita, mas, ao apresentarem a saída, ou seja, ao diagnosticarem os problemas, rearticulam os movimentos interno e externo na perspectiva para a materializaçáo das relaçóes econômico-sociais e político-ideológicas internas.

Disso resulta que náo são a ordem econômica mundial, a globalização e a competitividade, inerentes a esse processo, a causa da ineficiência das economias periféricas. A sua causa, antes de tudo, está nas próprias economias periféricas, isto é, na ineficiência produzida pelas suas economias "fechadas" à competitividade internacional e supostamente submersas em um desenvolvimento tecnologicamente atrasado, e também em uma crise do Estado, fundamentalmente responsável pela ineficiente integraçáo à economia globalizada. Isso tudo é congruente com uma argumentaçáo sintetizada da tese da crise do desenvolvimento na crise do Estado sustentada pelo socialliberalismo brasileiro (BRESSER-PEREIRA, 2000, p. 163-164).

Essa posição revela a noção moderna de soberania pretendida. Náo haveria contradição na defesa de uma reforma que pusesse o Estado mais intimamente a serviço do mercado. E, para fazer isso, a notável exposiçáo mostra o vigor cobrado às classes dominantes (notadamente às facçóes modernizantes e renovadoras) para a sua disputa no processo de reproduçấo e acumulaçấo de capital.

O social-liberalismo, distintivo em seus predicados, apresenta a argumentaçáo central das classes dominantes: a de que a reproduçáo e a acumulaçáo de capital náo pode prescindir do Estado burguês brasileiro. Como materialmente as classes dominantes praticam exaustivamente esse exercício estatal da reproduçáo e da acumulaçáo, a liçáo é aprendida com facilidade ao gosto de nossas oligarquias burguesas, o dever de casa é retomado da argumentaçáo e, como resultado, da consagraçáo do dever bem feito (BRESSER-PEREIRA, 2000, p. 164). 
A explicação vigorosa da descriçáo da crise comprova duas ilustres teses. A primeira, de que o desenvolvimento náo atingiu patamares avançados devido à ineficiência econômica interna de integração nacional à economia mundial, competitiva e tecnologicamente avançada. Assim, portanto, o desenvolvimentismo e o nacionalismo correspondem ao "fechamento" nacional da economia ao mercado mundial, ou seja, à incapacidade interna de integraçáo à economia mundial, representada na tese sobre um determinado conceito de dependência formulada por Falleto, Cardoso e Bresser- Pereira - este último incluído por ele mesmo nessa discussão (BRESSER-PEREIRA, 1996, 2000).

A segunda tese aponta que o desenvolvimentismo e o nacionalismo náo deram conta da integraçáo mundial tendo como base a justificada da argumentaçáo da tese da crise do Estado (BRESSER-PEREIRA, 1996, 2000), ou na tese da interpretaçáo da crise do Estado, apresentada por Bresser-Pereira e anunciada originalmente como resultado de sua elaboraçáo teórica. (BRESSERPEREIRA, 2000).

A crise do Estado, diante da superaçáo do modelo de desenvolvimento deve ser superada, pois se torna, agora, a única causa e consequência da crise econômica e política. Justifica-se, portanto, a partir da crise do Estado, a crise política e a crise econômica. Além disso, em uma sucessiva continuidade de problemas derivados dessa ordem interpretativa, arrolam-se todos os problemas estruturais ou setoriais, como problemas os educacionais. Essa é a extraordinária argumentaçáo teórica realizada particularmente pelos nossos liberais modernizantes com muita dedicação e presteza intelectual e de classe.

Essas duas teses permitiram uma explicaçâo racional e sistêmica das crises e dos problemas nacionais e internacionais e assumem importante função econômica e política para as classes dominantes. Sáo verdadeiras teses liberais proclamadas e realizadas, com expressivo aprofundamento, especialmente a partir da década de 1990, quando ganham força na composiçáo e na formação do bloco das classes dominantes na direçáo do aparelho de Estado brasileiro. Desse diagnóstico convergem mundialmente outros tantos, não menos nem mais liberais do que os que aqui se reproduzem.

Os elementos centrais que sustentam as justificativas e argumentaçóes dos liberais, particularmente em âmbito mundial, ganharam espaço no processo de recomposiçáo da hegemonia norte-americana basicamente a partir da década de 1960. Esse processo ocorre em várias dimensóes. No campo da acumulaçáo de capital sobre as forças produtivas e de trabalho ocorre reordenando e ampliando 
o domínio do e sobre o trabalho e os meios de produçáo, bem como reforçando o processo de marginalizaçáo e precarizaçáo das condiçóes de trabalho e sobrevivência. Na esfera financeira, com a aceleração da financeirizaçáo dos espaços, tempos e riquezas nacionais (LEHER, 1998).

Isso ocorre, no Brasil, de várias maneiras: endividamento crescente do Estado por meio do pagamento de juros; câmbio para as trocas comerciais e financeiras sustentado com base no dólar; venda de empresas estatais rentáveis aos capitais nacionais e transnacionais; aumento das reservas nacionais no mercado financeiro internacional; venda de títulos da dívida pública e açôes de empresas estatais; transferência de espaços públicos para a exploraçáo de empresas privadas, tais como pedágios, petróleo, terceirização de serviços sociais, reservas naturais etc.

A argumentaçáo e a justificativa elaborada pelos liberais (notadamente os liberais modernizantes e renovadores) em seus diagnósticos sáo excelentes fórmulas político-ideológicas para a crise contemporânea, que não seria do modo de produção que se sustenta na propriedade privada. Essa análise é pertinente, partindo obviamente de nossos liberais que apenas seguem seus caminhos na ordem burguesa e não estáo "fora do lugar".

Por isso, quando os liberais estáo preocupados em criar a noção moderna de soberania, estáo pensando e agindo a partir de uma interpretação da crise do Estado e, mais, de uma crise contemporânea que seria resultante da crise do Estado e concebida, portanto, como a reprodutora e a causadora da crise econômica e política.

Congruente com esse diagnóstico e justificando-o, Cardoso ao apresentar à sociedade brasileira o Plano Diretor da Reforma do Aparelho do Estado, aprovado em 1995, indica que: "A crise brasileira da última década foi também uma crise do Estado." (CARDOSO, 1995, p. 9).

$\mathrm{Na}$ introduçáo do Plano Diretor da Reforma do Aparelho do Estado, explicitando seu diagnóstico, a tese da crise do Estado está evidenciada e reafirma o pressuposto apresentado, além de sustentar a afirmaçáo de que a crise é geradora de instabilidade econômica e política (CARDOSO, 1995). Percebe-se, portanto, que o problema deriva fundamentalmente do Estado por dois elementos. O primeiro refere-se à interferência do Estado na esfera produtiva e empresarial, e o segundo é o equívoco do Estado mínimo proposto pela ideologia neoliberal. Esses dois argumentos sustentam ou reforçam as 
formulaçóes propostas para a reforma do Estado brasileiro realizadas, em grande medida, por meio do diagnóstico contido no Plano Diretor da Reforma do Aparelho do Estado.

A liçáo apresentada pelo liberalismo modernizante: primeiro, para fortalecer o mercado é necessário o Estado; segundo, o Estado regulador, como a expressáo da composiçáo das classes dominantes, deve ser forte. Desse modo, só será possível torná-lo forte a partir da ideia de que é necessário que a presença do Estado seja mínima no campo da recomposiçáo das políticas sociais para devolver a elas o seu caráter mercadológico na recomposiçáo do processo de reproduçáo da acumulaçáo, particularmente sob a égide da esfera financeira. Assim, o Estado deve ser reformado, pois ele continua sendo um elemento fundamental da acumulaçáo de capital e da coordenaçáo política mais geral, ao reorganizar a repartiçáo da renda e da riqueza.

Desse modo, o diagnóstico que sustenta essa justificativa compreende a reafirmaçáo do mercado como o objetivo do Estado - com sua função "[...] reguladora, no quadro de uma economia de mercado [...]" (CARDOSO, 1995, p. 9) -, expressão da composiçáo social resultante das classes sociais e da luta de classes na sociedade capitalista.

Esse diagnóstico, apresentado na justificativa do Plano Diretor da Reforma do Aparelho do Estado, converge com o diagnóstico exposto por ocasiāo da formulação apresentada na Exposiçáo de Motivos do Plano Real. O ministro da Fazenda observava que "[...] a desordem financeira e administrativa do Estado é a principal causa da inflação crônica que impede a sustentaçáo do crescimento, perpetua as desigualdades e mina a confiança nas instituiçóes" (CARDOSO, 1994, p. 114). Defendia, coerentemente, a reforma do Estado por este ser o responsável pela crise política e econômica do país. Zeloso no diagnóstico, previa ainda o que o Estado brasileiro deveria promover como açốes oriundas dessa perspectiva econômica e política. As reformas, portanto, dependem da garantia estatal.

Essas proposiçóes e o programa político proposto para a realizaçáo dessas açóes, sejam elas estatais, econômicas ou sociais, afirmam que náo postulam um ordenamento apenas a partir do mercado e náo admitem o mercado sem a máo visivel do Estado. (BRESSER-PEREIRA, 1996, p. 24).

Dessa forma, os liberais consideram que a lei da natureza econômica e política existe há muito tempo e basta inová-la em suas condiçôes e sustentaçôes 
teóricas e pragmáticas. Esta conjugaçáo ganha força, compondo-se de uma disposição genuinamente "fundamentalista", ao retomar-se o liberalismo econômico e rejeitarem-se os compromissos sociais que o capitalismo contemporâneo sustentou em determinada organizaçáo social, perdendo, talvez, alguns anéis. E, para consolidar essa mobilidade inovadora, comporta uma característica, dentre outras, que é fundamental, pois assegura a envergadura teórica de seus intelectuais altamente aguerridos, sofisticados e definitivamente posicionados em fraçóes das classes dominantes, as quais representam com esmero próprio da sua emergência e da sua constituiçáo política e material. (CRUZ, 2002).

Desses liberais modernizantes, o campo da política educacional brasileira náo obtém menos esforço e dedicaçáo política e intelectual. Tanto que, já articulados e afinados teórica e politicamente, eles convergiam e compunham a facçáo que disputava a direçáo do pacto burguês. Já se compreendia, portanto, que a crise econômica, educacional e social estava fundamentalmente imbricada na crise do Estado. Por isso, Mello (1990, p. 71-72) observa:

Há hoje um consenso razoável sobre a necessidade de diminuir o tamanho do Estado na economia. Um Estado agigantado, cuja expansáo ocorreu de modo inorgânico e segmentado, pelo enfraquecimento da administraçáo direta, gerou a ineficácia, a incapacidade de governar, a formulaçáo de políticas contraditórias e sobretudo uma enorme dificuldade de instituir controles públicos sobre a máquina estatal.

$\mathrm{Na}$ disputa com outras fraçōes das classes dominantes e no enfrentamento das classes dominadas é que emergiram as proposiçóes e os argumentos dos programas econômico-sociais e político-ideológicos defendidos e realizados no país pelos liberais modernizantes, particularmente as proposiçóes que aqui discutimos empreendidas pelos sociais-democratas nos governos FHC (19952002) que fertilizaram a economia, a política e a gestáo estatal do Estado brasileiro. 


\section{Notas}

1 Temática analisada em Tese de Doutorado intitulada O Capital Financeiro e a Educaçáo no Brasil. (DEITOS, 2005).

2 Termo usado por Fernando Henrique Cardoso na Exposiçáo de Motivos do Plano Real em dezembro 1993. (CARDOSO, 1994).

3 O Plano Real foi anunciado oficialmente em 7 de dezembro de 1993, cf. Exposiçáo de motivos, n. 395, encaminhada ao presidente da República Itamar Franco pelo ministro da Fazenda Fernando Henrique Cardoso. (CARDOSO, 1994).

4 O núcleo estratégico é o centro no qual se definem a lei e as políticas públicas e se garante, em nível alto, seu cumprimento. É formado pelo presidente ou primeiro-ministro e seus ministros, pelo Parlamento, pelos Tribunais Superiores e pela cúpula dos servidores civis. Autoridades estaduais e das grandes cidades também podem ser consideradas parte do núcleo estratégico. (Nota do autor no original) (BRESSER-PEREIRA, 2001, p. 36).

\section{REFERÊNCIAS}

\section{BANCO MUNDIAL; CORPORAÇÁO FINANCEIRA}

INTERNACIONAL. Barreiras jurídicas, administrativas e politicas aos investimentos no Brasil: o quadro dominante das leis e das políticas e o papel da promoçáo dos investimentos. Washington, D.C.: Serviço de Assessoramento sobre Investimentos Estrangeiros, 2001. v. 1.

BRASIL. Presidência da República. Governo Fernando Henrique Cardoso. Nova politica industrial: desenvolvimento e competitividade. Brasília, DF: Presidência da República, 1998.

BRESSER-PEREIRA, L. C. A reforma gerencial de 1995. Cadernos Adenauer, Sáo Paulo, v. 3, jul. 2001, p. 29-46. Burocracia e reforma do Estado.

Apresentaçáo. In: BRESSER-PEREIRA, L. C.; SPINK, P. K. (Org.). Reforma do Estado e administração pública gerencial. Traduçáo de Carolina Andrade. 3. ed. Rio de Janeiro: Ed. da FGV, 1999a. p. 7-13. 
BRESSER-PEREIRA, L. C. Crise econômica e reforma do Estado no Brasil: para uma nova interpretaçáo da América Latina. Traduçáo de Ricardo Ribeiro e Martha Jalkauska. Sáo Paulo: Ed. 34, 1996.

. Gestáo do setor público: estratégia e estrutura para um novo Estado. In: BRESSER-PEREIRA, L. C.; SPINK, P. K. (Org.). Reforma do Estado e administração pública gerencial. Traduçáo de Carolina Andrade. 3. ed. Rio de Janeiro: Ed. da FGV, 1999b. p. 21-38.

. Da administraçáo pública burocrática à gerencial. In: BRESSERPEREIRA, L. C.; SPINK, P. K. (Org.). Reforma do Estado e administraçáo pública gerencial. Traduçáo de Carolina Andrade. 3. ed. Rio de Janeiro: Ed. da FGV, 1999c. p. 237-270.

. Desenvolvimento e crise no Brasil: história, economia e política de Getúlio Vargas a Lula. Sáo Paulo: Ed. 34, 2003.

. Economia conservadora e economia progressista. Revista de Economia Política, Sáo Paulo, v. 5, n. 4 (20), p. 5-14, out./dez. 1985.

. Influências e contribuiçóes. Revista de Economia Política, São Paulo, v. 20, n. 1 (77), p. 155-176, jan./mar. 2000.

CARDOSO, F. H. Revista VEJA, São Paulo, 10 set. 1997. (Entrevista, Rev. Número 1512) Disponível em: <http://veja.abril.com.br/100997/p_022. html>.

. Reforma do Estado. In: BRESSER-PEREIRA, L. C.; SPINK, P. K. (Org.). Reforma do Estado e administraçáo pública gerencial. Traduçáo de Carolina Andrade. 3. ed. Rio de Janeiro: Ed. da FGV, 1999. p. 15-19.

. FHC defende novo 'pacto constitucional' em 2007. Folha de Sáo Paulo, Sáo Paulo, 5 out. 2003. p. A4.

- Plano Fernando Henrique Cardoso: exposiçáo de motivos n. 395, de 7 de dezembro de 1993. Revista de Economia Política, Sáo Paulo, v. 14, n. 2 (54), p. 114-131, abr./jun. 1994.

- Apresentação. In: BRASIL. Presidência da República. Câmara da Reforma do Estado. Ministério da Administraçáo Federal e Reforma do Estado. Plano diretor da reforma do aparelho do Estado. Brasília, DF, 1995. p. 9-12. 
CARDOSO, F. H.; FALETTO, E. Dependência e desenvolvimento na América Latina: ensaio de interpretação sociológica. 2. ed. Rio de Janeiro: Zahar, 1973.

CRUZ, S. C. V. Organizaçóes internacionais e reformas neoliberais: reflexóes a partir do tema da propriedade intelectual. Campinas, SP: IFCH/ UNICAMP, 2002.

DEITOS, R. A. O Capital Financeiro e a Educação no Brasil. $2005.357 \mathrm{f}$. Tese (Doutorado em Educaçáo) - Universidade Estadual de Campinas, Campinas, 2005. Disponível em: <www.unicamp.br/FE/Biblioteca/Acervo Digital>. Acesso em: 10 dez. 2010.

FIORI, J. L. A instabilidade e crise do Estado na industrializaçāo brasileira. Rio de Janeiro: UFRJ; IEI, 1988. Tese de Concurso de Professor Titular. Brasil no espaço. Petrópolis, RJ: Vozes, 2001a. . Em busca do dissenso perdido: ensaios críticos sobre a festejada crise do Estado. Rio de Janeiro: Insight, 1995. . Para um diagnóstico da "modernizaçáo" brasileira. In: FIORI, J. L. (Org.). Polarizaçáo mundial e crescimento. Petrópolis, RJ: Vozes, 2001b. p. 269-289.

FRIEDMAN, M. Capitalismo e liberdade. Traduçáo de Luciana Carli. Sáo Paulo: Abril Cultural, 1984.

LEHER, R. Da ideologia do desenvolvimento à ideologia da globalização: a educaçáo como estratégia do Banco Mundial para "alívio" da pobreza. 1998. 267 f. Tese (Doutorado em Educaçáo) - Universidade de Sáo Paulo, Sáo Paulo, SP, 1998.

MELLO, G. N. de. Social democracia e educação: teses para discussão. 2. ed. São Paulo: Cortez: Autores Associados, 1990.

MÉSZÁROS, I. Para além do capital: rumo a uma teoria da transiçấo. Tradução de Paulo César Castanheira e Sergio Lessa. Sáo Paulo: Boitempo; Campinas, SP: Ed. da Unicamp, 2002. p. 94-134.

SODRÉ, N. W. A farsa do neoliberalismo. 3. ed. Rio de Janeiro: Graphia, 1996. 


\section{Democratic social liberalism and the reform of the brazilian State (1995-2002)}

\section{Abstract}

This article analyzes social-democratic liberalism and the reform of the Brazilian State conducted from 19952002 in propositions presented in the arguments of a faction that led the political process and the Brazilian State apparatus based on a victorious coalition in 1994, which was composed through actions conducted by the Brazilian Social Democratic Party (PSDB). The faction was comprised by the national bourgeois pact and expressed in the political leadership of the intellectual Fernando Henrique Cardoso (FHC), who was elected president of the republic in 1994. To address these issues, the article analyzes the most general aspects of the reform of the Brazilian state, to understand how a certain liberal version emerged and how its political and ideological arguments were consummated and came together, based on a certain faction of the dominant classes, the political and economic leadership of the national bourgeois pact. This leadership was strengthened in 1995 with the initiation of the FHC administrations and its efforts to reform the Brazilian State, culminating in the approval in 1995 of the Master Plan for the Reform of the State Apparatus.

Keywords: Liberalism. Social reform. Fernando Henrique Cardoso. Brazilian State.

\section{El liberalismo social demó- crata y la reforma del Estado brasilero (1995-2002)}

\section{Resumen}

El presente artículo realiza un análisis sobre el liberalismo social demócrata y la reforma del Estado brasilero (19952002) como proposiciones presentadas en los argumentos de una facción que lideró el proceso político y el aparato del Estado brasilero, en el marco de una coalición victoriosa en 1994, generada a partir de acciones conducidas por el PSDB - Partido de la Social Democracia Brasilera -; facción que aglutinó el pacto burgués nacional expresado en la representación del liderazgo político del intelectual Fernando Henrique Cardoso, electo presidente de la República, en 1994. Para tratar de estas cuestiones, el artículo analiza los aspectos más generales de la reforma del Estado brasilero, para comprender como surgió una determinada versión liberal y cómo sus argumentos políticos e ideológicos se consolidaron a partir de una determinada facción de las clases dominantes, del liderazgo político y económico del pacto burgués nacional, fortalecido a partir de 1995 con el inicio de los gobiernos de FHC, y consecuentemente, con el inicio de más una reforma del Estado brasilero, culminando con la aprobación, también en 1995, del Plano Director de la Reforma del Aparato de Estado.

Palabras clave: Liberalismo. Reforma social. Cardoso, Fernando Henrique. Estado brasilero. 


\section{Roberto Antonio Deitos}

E-mail: rdeitos@uol.com.br

Recebido em: 18/7/2010

Versáo final recebida em: 13/10/2011

Aprovado em: 29/2/2012 